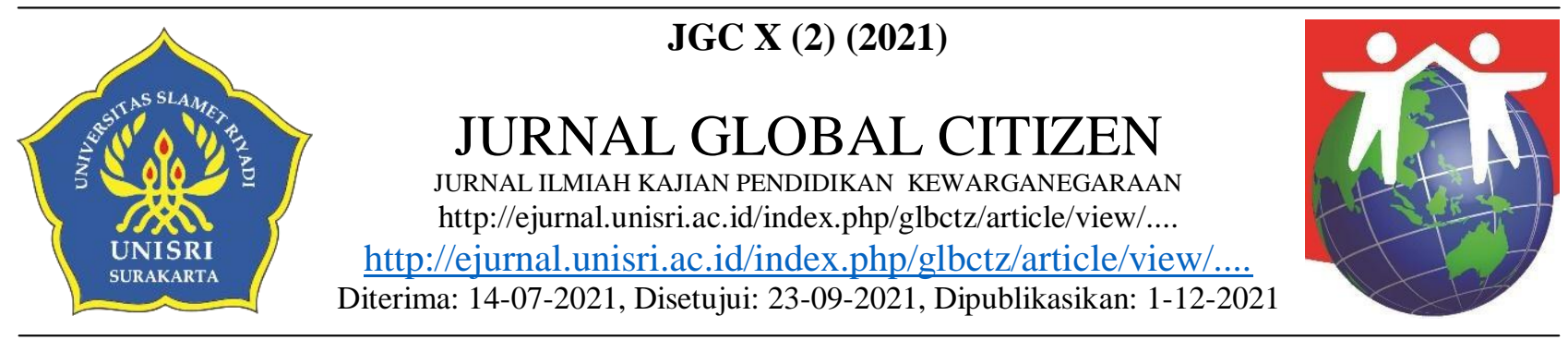

\title{
PENGUATAN KARAKTER MAHASISWA MELALUI PEMBELAJARAN PENDIDIKAN PANCASILA
}

\author{
Sutoyo \\ Email : sutoyopratama@gmail.com \\ Fakultas Keguruan dan Ilmu Pendidikan \\ Universitas Slamet Riyadi Surakarta
}

\begin{abstract}
ABSTRAK
Pancasila sebagai dasar negara dan pandangan hidup bangsa mengandung konsekuensi logis untuk dipahami dan diimplementasikan dalam kehidupan bermasyarakat, berbangsa dan bernegara. Penelitian ini bertujuan untuk : (1) menghasilkan profil pembelajaran pendidikan Pancasila yang saat ini berlangsung; (2) Mengetahui penguatan karakter mahasiswa melalui pembelajaran pendidikan Pancasila ;(3) Mengetahui faktor-faktor yang mempengaruhi implementasi pembelajaran pendidikan Pancasila dalam penguatan karakter mahasiswa.

Penelitian ini merupakan penelitian kualitatif. Strategi penelitian menggunakan sudi kasus tunggal. Subjek penelitian ini adalah para dosen Pancasila dan mahasiswa yang menempuh mata kuliah pendidikan Pancasila. Teknik pengumpulan data menggunakan teknik wawancara, observasi, angket dan dokumentasi. Validitas data menggunakan teknik trianggulasi. Data yang terkumpul dinalisis dengan teknik interaktif.

Hasil penelitain dapat disimpulkan bahwa : (1). Pembelajaran pendidikan Pancasila dilaksanakan dengan baik sesuai ketentuan. Masih ada dosen yang mengajar belum seseuai dengan kompetensinya.. Pada umunya dosen dalam mengajar masih menggunakan model pembelajaran konvensional melalui metode ceramah bervariasi; (2) Pendidikan Pancasila sebagai mata kuliah memiliki peran yang strategis dalam pembentukan karakter mahasiswa; (3) Ada beberapa faktor yang mempengaruhi implementasi pembelajaran pendidikan Pancasila dalam penguatan pendidikan karakter yaitu : (a) dosen pengajar; (b) mahasiswa; (c) materi pembelajaran ; (d) sarana prasarana; dan (e) lingkungan.
\end{abstract}

Kata kunci : Pembelajaran, Karakter, Pendidikan Pancasila 
PENDAHULUAN

Pancasila sebagai pandangan hidup bangsa Indonesia mengandung konsekuensi, bahwa semua sikap dan perilaku bangsa Indonesia dalam kehidupan bermasyarakat, berbangsa dan bernegara harus berdasarkan nilai-nilai Pancasila. Hal ini berarti nilai-nilai Pancasila harus di aktualisasikan oleh setiap warga negara Indonesia dalam kehidupan bermasyarakat, berbangsa dan bernegara. Jika nilai-nilai Pancasila tidak diaktualisasikan dengan baik dan benar, maka akan berdampak negatif terhadap kelangsungan kehidupan bermasyarakat, berbangsa dan bernegara.

Masih banyaknya kasus penyalahgunaan narkoba, munculnya kasus kriminalitas, pergaulan bebas, tindak kekerasan dan perilaku tidak terpuji dikalangan mahasiswa menjadi bukti nyata penyimpangan terhadap nilai-nilai Pancasila (Mawardi, 2009). Di sisi lain Supriyoko (2003) menyatakan, bahwa tidak sedikit generasi muda yang gagal menampilkan akhlak yang terpuji, sikap sopan santun, sifat ranah, tenggang rasa, rendah hati, suka menolong, solidaritas sosial, yang merupakan jati diri bangsa yang seakan akan sudah hilang dan tidak lagi melekat secara kuat dalam diri mahasiswa. Hal ini diperkuat oleh Samani dan Haryanto (2012) dan Muhajir (2011) yang menyatakan, bahwa kenakalan remaja yang sering terjadi seperti perkelaian antar mahasiswa, penggunaan narkoba adalah demoralisasi di kalangan mahasiswa.
Hal tersebut di atas menunjukkan bahwa karakter mahasiswa belum sesuai harapan. Menyikapi hal tersebut dipandang perlu untuk mengimplementasikan pembelajaran pendidikan Pancasila dalam rangka penguatan karakter mahasiswa.

Pendidikan Pancasila sebagai mata kuliah umum wajib diikuti oleh seluruh mahasiswa. Pendidikan Pancasila sebagai mata kuliah umum memiliki bobot dua SKS. Dua SKS memiliki konsekuensi bahwa pembelajaran pendidikan Pancasila dilaksanakan melalui tatap muka 100 menit, tugas terstruktur 100 menit dan tugas mandiri 100 menit. Melalui pembelajaran pendidikan Pancasila diasumsikan dapat memperkuat karakter mahasiswa. Hal ini disebabkan pendidikan Pancasila memuat materi, diantaranya materi tentang pengamalan nilai-nilai Pancasila.

Berdasarkan hal tersebut di atas dapat dirumuskan permasalahan sebagai berikut : (1). Bagaimanakah pelaksanaan pembelajaran pendidikan Pancasila yang saat ini berlangsung ?; (2). Apakah pendidikan Pancasila dapat meningkatkan penguatan karakter mahasiswa ?; (3). Faktor-faktor apa sajakah yang mempengaruhi pelaksanaan pembelajaran pendidikan Pancasila dalam penguatan karakter mahasiswa ?

Berdasarkan rumusan masalah tersebut di atas, tujuan penelitian ini adalah untuk :

(1). Menghasilkan profil pembelajaran pendidikan Pancasila yang saat ini berlangsung; 
(2). Mengetahui penguatan karakter mahasiswa melalui pembelajaran pendidikan Pancasila; (3). Mengetahui faktor-faktor yang mempengaruhi implementasi pembelajaran pendidikan pancasila dalam penguatan karakter mahasiswa.

\section{METODE PENELITIAN}

Penelitian ini dilaksanakan di Universitas Slamet Riyadi Surakarta pada semester gasal tahun akademik 2020/2021. Penelitian ini merupakan penelitian kualitatif dengan bentuk studi kasus tunggal. Dimana penelitian ini hanya meneliti tentang pelaksanaan pembelajaran pendidikan Pancasila yang berlangsung di Universitas Slamet Riyadi Surakarta pada semester gasal tahun akademik 2020/2021.

Data dalam penelitian ini berupa data tentang pelaksanaan pembelajaran pendidikan Pancasila dan data tentang kondisi karakter mahasiswa Universitas Slamet Riyadi Surakarta. Sumber data dalam penelitian ini meliputi dosen pendidikan Pancasila dan mahasiswa yang menempuh mata kuliah pendidikan Pancasila. Data dalam penelitian ini dikumpulkan dengan menggunakan teknik wawancara, observasi, angket dan dokumentasi.

Validitas yang digunakan dalam penelitian ini adalah teknik trianggulasi, yakni trianggulasi sumber dan trianggulasi metode. Data yang terkumpul dianalisis dengan menggunakan teknik analisis interaktif yang meliputi : 1) pengumpulan data; 2) reduksi data; 3) sajian data; dan 4) verifikasi/ penarikan kesimpulan.

\section{HASIL DAN PEMBAHASAN}

1. Proses pembelajaran pendidikan Pancasila yang dilaksanakan oleh dosen

Hasil temuan menunjukkan, bahwa kualifikasi dosen pendidikan Pancasila sudah sesuai dengan ketentuan tenaga pengajar dimana dosen harus memiliki kualifikasi pendidikan S2 atau S3, namun kompetensinya ada yang tidak relevan. Hal ini menunjukkan adanya konsistensi dan komitmen pengelola pendidikan (Yayasan pendidikan) dalam rangka meningkatkan kualitas pendidikan di Indonesia.

Kondisi ini merupakan sesuatu yang membanggakan. Hal ini sejalan dengan tuntutan Undang-Undang Guru dan Dosen No 14 Tahun 2005 Bab IV asal 8 dan 9. Pasal 8 menyatakan bahwa guru dan dosen wajib memliki kualifikasi akademik, kompetensi, sertifikat pendidik, sehat jasmani dan rohani, serta memiliki kemampuan untuk mewujudkan tujuan pendidikan nasional. Upaya dosen dalam rangka memenuhi tugasnya, dosen melakukan upaya peningkatan kualitas pembelajaran. Hal-hal yang dilakukan dosen dalam rangka meningkatkan kualitas pembelajaran diantaranya, dosen selalu berupaya membuat RPS. Membuat perencanaan pembelajaran merupakan keharusan bagi seorang dosen. Hal ini disebabkan salah satu faktor yang akan menentukan kualitas pembelajaran 
adalah perencanaan pembelajaran yang dibuat oleh dosen Proses pembelajaran tidak mungkin akan berjalan dengan baik dan berkualitas jika tidak ada perencanaan yang baik pula. Sani (2013 : 88) menyatakan, bahwa dalam perencanaan pembelajaran perlu dilakukan oleh dosen secara baik, karena dalam perencanaan pembelajaran terdapat model, strategi, dan metode yang akan digunakan guru dalam pembelajaran. Oleh karena itu kualitas pembelajaran sangat ditentukan oleh beberapa faktor. Salah satu diantaranya adalah perencanaan pembelajaran.

Dosen di samping berfungsi sebagai perencana juga berfungsi sebagai manager atau pengelola kelas. Tanggung jawab kelas ada pada guru. Saat sekarang sudah terjadi perubahan paradigma dalam pengelolaan kelas. Jika zaman dulu pembelajaran itu berpusat pada dosen saat sekarang pembelajaran berpusat pada mahasiswa. Oleh karena itu dosen harus benar-benar mampu mengelola kelas dengan baik sehingga pembelajaran menjadi menarik, tidak membosankan dan tujuan pembelajaran dapat tercapai sesuai harapan. Mengelola kelas membutuhkan kemampuan khusus bagi seorang guru. Sejalan dengan hal ini Mudjiman (2011 : 120) menyatakan bahwa suasana kelas perlu diciptakan oleh para pemegang peran diantaranya oleh dosen. Jika kelas tidak dikelola dengan baik, maka akan terjadi suasana kelas yang ramai, tidak terkontrol bahkan dimungkinkan tujuan pembelajaran sulit untuk diwujudkan. Ada dua hal pokok yang harus dikuasai oleh dosen pada saat dosen sudah berada di ruang kelas, yakni : penguasaan materi pelajaran dan cara untuk menyampaikan materi kepada peserta didik. Hal ini ada kaitannya dengan kompetensi dosen , yakni kompetensi profesional dan kompetensi pedagogik.

Hasil temuan menunjukkan, bahwa para dosen pendidikan Pancasila dalam melaksanakan pembelajaran, jarang menyiapkan media pembelajaran secara khusus sesuai dengan materi yang disampaikan. Hal ini berdampak terhadap kualitas pembelajaran. Diantaranya adalah pembelajaran kurang menarik, membosankan, peserta didik kurang konsentrasi pada pembelajaran, peserta didik ramai dalam proses pembelajaran, dan kurang tertib. Berkaitan dengan media pembelajaran. Anitah (2009) menyatakan, bahwa pemilihan media perlu mendapatkan perhatian, karena fungsi media sangat strategis dalam pelaksanaan pembelajaran. Pembelajaran akan menarik dan mudah dipahami oleh peserta didik apabila dosen merancang media secara cermat dan dapat menggunakan sesuai dengan fungsinya.

Hasil temuan menunjukkan, bahwa para dosen pendidikan Pancasila pada umunya kurang memahami model-model pembelajaran inovatif. Model pembelajaran yang digunakan adalah model pembelajaran 
yang konvensional, yakni ceramah bervariasi. Hal ini dilakukan karena model konvensional ceramah bervariasi merupakan cara yang mudah untuk dilaksanakan dan sudah biasa dilakukan sejak menjadi dosen.

2. Penguatan Karakter melalui Pendidikan Pancasila

Pendidkan Pancasila sebagai mata kuliah memberikan konstribusi dalam pengauatan karakter mahasiswa. Hal ini dikarenakan matari pendidikan Pancasila salah satunya adalah materi nilai-nilai Pancasila. Sebagai konsekuensi logis dan moral sebagai mahasiswa yang telah memahami nilai-nilai Pancasila tentunya memilki kewajiban moral untuk menimplementasikan nilai-nilai Pancasila dalam kehidupan bermnasyarakat berbangsa dan bernegara.

Lickona (1992) menyatakan bahwa pendidikan nilai akan menghasilkan karakter. Ada tiga komponen karakter yang baik, yakni pengetahuan tentang moral (moral knowing), perasaan tentang moral (moral feeling), dan perbuatan moral (moral action). Ketiga komponen tersebut menunjuk pada tahapan pemahaman sampai pelaksanaan nilai dalam kehidupan sehari-hari. Ketiganya tidak serta merta terjadi pada diri seseorang, melainkan bersifat prosedural. Artinya tahapan ketiga hanya mungkin terjadi setelah tercapai tahap kedua dan tahap kedua akan tercapai setelah tahapan pertama.

Kenyataannya ketiga tahapan tidak terjadi secara utuh, dimana ada orang yang hanya sampai pada pengetahuan moral dan berhenti sebatas pada memahami. Di sisi lain orang lain sampai pada tahap sikap moral, dan yang lain mengalami perkembangan dari pengetahuan moral sampai pada tindakan moral.

Pendidikan Pancasila seharusnya tidak hanya sampai pada pengetahuan tentang Pancasila, sebab sebatas pada tahu atau memahami tanpa mengamalkan. Hal ini hanya akan menghasilkan orang-orang yang cerdas tetapi tidak bermoral. Maka amtlah penting pendidikan Pancasila dilanjutkan pada sikap moral. Sikap moral merupakan aspek lain yang harus ditanamkan kepada mahasiswa sehingga dapat menjadi energy dari diri manusia untuk dapat bertindak sesuai dengan prinsip.prinsip moral.

Langkah yang amat penting dalam pendidikan Pancasila adalah pengamalan Pancasila sebagai tindakan moral. Tindakan moral adalah bagaimana membuat pengetahuan Pancasila dapat diwujudkan dalam bentuk pengamalan Pancasila.

3. Faktor-Faktor yang Mempengaruhi Pembelajaran Pendidikan Pancasila sebagai penguatan karakter

Ada beberapa faktor yang mempengaruhi implementasi pembelajaran pendidikan Pancasila dalam penguatan pendidikan karakter yaitu : (a) dosen pengajar; (b) mahasiswa; (c) materi pembelajaran ; (d) sarana dan prasarana lingkungan; dan (e) lingkungan. 
Dosen memiliki peran penting dalam pembelajaran. Peran dosen tidak bisa digantikan, meskipun teknologi sudah mengalami kemajuan yang sangat pesat. Hal ini disebabkan kehadiran dosen akan berdampak secara psikologis terhadap perkembangan mental dan psikis mahasiswa. oleh karena itu dosen hendaknya meiliki beberapa keterampilan dasar mengajar antara lain, keterampilan membuat perencanaan pembelajaran, keterampilan membuka dan menutup perkuliahan, keterampilan bertanya, keterampilan menjelaskan, keterampilan memberikan variasi, dan keterampilan mengelola kelas.

Di sisi lain mahasiswa sebagai subjek dan objek dalam pembelajaran akan sangat menentukan berhasil tidaknya dalam mengikuti perkuliahan. Hal ini sangat tergantung dari beberapa hal, antara lain : kemampuan awal mahasiswa, tingkat kebutuhan mahasiswa, minat dan motivasi mahasiswa.

Materi pembelajaran pendidikan Pancasila secara substansi sudah dirumuskan oleh asosiasi dosen Pancasila. Hal yang perlu mendapatkan perhatian adalah pengembangan materi yang disesuaikan dengan kondisi mahasiswa. Mengingat mahasiswa sangat heterogin, baik dari sisi kemampuan, asal daerah, tingkat kebutuhan, mimat dan motivasinya.

Sarana prasarana dan suasana lingkungan kampus sangat menentukan tingkat keberhasilan dalam proses pembelajaran. Sarana prasarana yang lengkap. Ruang kelas dan lingkungan kampus yang nyaman menjadi faktor penting. Hal ini menjadi tanggung jawab penyelenggara dan pengelola perguruan tinggi untuk mewujudkannnya.

\section{KESIMPULAN}

Pendidikan Pancasila sebagai sebagai mata kuliah wajib tempuh di perguruan tinggi memiliki peran penting dalam penguatan karakter mahasiswa. Oleh karenanya pelaksanaan pembelajaran pendidikan Pancasila perlu ditingkatkan dalam hal penggunaan model pembelajaran dan media pembelajaran.

Ada beberapa faktor yang mempengaruhi pembelajaran pendidikan Pancasila di perguruan tinggi, antara lain : faktor dosen, mahasiswa, materi pembelajaran, srana prasarana dan lingkungan pembelajaran. Oleh karena itu bagai para pengelola perguruan tinggi baik yayasan, rektorat, dekanat dan program studi untuk mensikapi secara bijaksana demi terwujudnya pembelajaran yang baik yang meghasilkan mahasiswa yang berkarakter.

\section{DAFTAR PUSTAKA}

Anitah, S. (2009). Media Pembelajaran. Surakarta : Panitia Sergur Rayon 113 FKIP UNS

Budiyono, K. (2009). Pendidikan Pancasila untuk Perguruan Tinggi. Bandung : Alfabeta 
Darmodihardjo, D. (1988). Pancasila, Suatu Orientasi Singkat. Jakarta : Balai Pustaka

Heuken, A.SJ. (1988). Ensiklopedi Populer Politik Pembangunan Pancasila. Jakarta : Yayasan Cipta Loka Caraka

Kaelan, M.S. (2002). Filsafat Pancasila. Yogjakarta : Paradigma.

Lickona, Th. (1992). Educating for Cbaracter, How our school can teach respect and responsibility. New York: Holt, Rinechart and Winston.

Mawardi, L. (2009). Evaluasi Pendidikan Nilai, Perkembangan Moral Keagamaan Mahasiswa. Yogjakarta : Pustaka Pelajar.

Muhajir, A. (2011). Ilmu Pendidikan Perspektif Kontekstual. Yogjakarta : Ar-Ruzz Media.

Mudjiman, H. (2011). Belajar mandiri, Pembekalan dan Penerapan. Surakarta : UNS Press.

Notonagoro. (1971). Pengertian Dasar bagi Implementasi Pancasila untuk ABRI. Jakarta : Departemen Pertahanan dan Keamanan (1974). Pancasila Dasar Falsafah Negara. Jakarta : Pantjuran Tudjuh. (1975). Pancasila secara Ilmiah Populer. Jakarta : Pantjuran Tudjuh.

Oesman,O. dan Alfian. (1993). Pancasila sebagai Ideologi Dalam Berbagai Bidang Kehidupan bermasyarakat, Berbangsa dan bernegara. Jakarta : BP7.

Samani, M dan Haryanto. (2012). Konsep dan Model Pendidikan Karakter. Bandung : PT. Remaja Rosda Karya.

Sani, R.A. (2013). Inovasi Pembelajaran. Jakarta : PT. Bumi Aksara

Soegito, A.T. (2002). Pendidikan Pancasila. Semarang : UPT MKU UNNES.
Sugiyono. (2007). Memahami Penelitian Kualitatif. Bandung : Alfabeta.

(2010). Metode Penelitian Pendidikan : Pendekatan Kuantitatif, Kualitatif, dan $R$ \& D. Bandung : Alfabeta.

(2016). Metode Penelitian Kuantitatif, Kualitatif, dan Kombinasi (Mix Methods). Bandung : Alfabeta.

Suhadi. (2001). Pendidikan Pancasila. Yogjakarta : Yayasan Pembinaan Fakultas Filsafat UGM.

Supriyoko. (2003). Menuju Masyarakat Tertib Damai Salam Bahagia sebagai karakter Bangsa Masa Depan. Makalah disampaikan dalam forum sarasehan kebudayaan. Yogjakarta 1920 Mei 2003. 